\author{
ks. Arkadiusz Cygański ${ }^{1}$ \\ 0000-0002-8056-8186 \\ Uniwersytet Papieski Jana Pawła II w Krakowie
}

\title{
Rozeznawanie i interpretowanie znaków czasów: egzegeza homilijna działania Ducha Świętego w życiu Ludu Bożego
}

Homilia rodzi się pomiędzy autentycznym kerygmatem biblijnym i aktualnymi potrzebami wspólnoty w kontekście celebrowanego w liturgii Misterium Chrystusa ${ }^{2}$. Homilista, jak podaje papież Franciszek, kontempluje Słowo, a także lud (por. EG 154)3. Czyta on księgę biblijną i życie członków zgromadzenia liturgicznego ${ }^{4}$, aby „rozpoznać serce swojej wspólnoty (por. EG 137). W adhortacji apostolskiej Evangelii gaudium papież stwierdził, że to Duch Święty, który „inspirował Ewangelię i działa w Ludzie Bożym, wskazuje również, jak powinno się wsłuchiwać w wiarę ludu i jak powinno się głosić słowo w każdej Eucharystii” (EG 139). Dlatego

1 Ks. dr Arkadiusz Cygański - kapłan diecezji zielonogórsko-gorzowskiej. Absolwent Uniwersytetu Papieskiego Jana Pawła II w Krakowie i Studium Retoryki Uniwersytetu Jagiellońskiego. Związany z Ruchem Światło-Życie. Zainteresowania: liturgia, komunikacja homilijna, zwłaszcza dialog. E-mail: xcarek@interia.pl.

2 Por. H. Simon, Kazanie biblijne. Teoria przepowiadania Bruno Drehera (1911-1971), Opole 1995, s. 81-86.

3 Franciszek, Adhortacja apostolska „Evangelii gaudium” o głoszeniu Ewangelii we wspótczesnym świecie, Kraków 2013 (dalej: EG).

4 Por. J. Twardy, Aktualizacja słowa Bożego w kaznodziejstwie, Przemyśl 2009, s. 145. 
przygotowanie homilii uwzględnia trzy czynności: 1) egzegezę biblijną, która zmierza do wyrażenia słowa Bożego, 2) hermeneutykę liturgiczną tego słowa, która wyraża ponadto wiarę Kościoła i 3) analizę antropologiczną życia słuchaczy homilii. Wymagają one przenikliwego spojrzenia i namysłu. Kerygmat biblijny musi bowiem dotyczyć autentycznych problemów współczesnego człowieka. Rzeczywistość współczesnego człowieka jest dla homilii kontekstem decydującym, a Ewangelia żyje w Kościele, gdy jest w relacji dialektycznej do życia ${ }^{5}$. W przeciwnym razie przepowiadaniu grozi biblicyzm albo antropocentryzm ${ }^{6}$. W homilii należy brać pod uwagę zarówno słowo Boże ujęte w aktualnym kontekście świata, jak i rzeczywistość świata w świetle słowa Bożego. Słowo Boże należy głosić w dialogu ze światem ${ }^{7}$, w sposób adekwatny do mentalności i życia słuchaczy, uwzględniając współczesne warunki historyczne, społeczne i kulturowe (por. NOWMR 65; IO 54; LI 2a) ${ }^{8}$. Homilista powinien więc znaleźć egzystencjalny „punkt ciężkości” tekstu biblijnego ${ }^{9}$ oraz uchwycić „moment współczesności w homilii” ${ }^{10}$. Chodzi o swoistą „egzegezę współczesności” (ks. J. Twardy) ${ }^{11}$, czy też „antropologię homiletyczną" (Z. Grzegorski) ${ }^{12}$. W tym kontekście stosuję pojęcie egzegezy homilijnej działania Ducha Świętego w Ludzie Bożym, w znaczeniu

5 Por. A. Cygański, Dialogiczny wymiar homilii po Soborze Watykańskim II, Kraków 2018, s. $288-315$.

6 Por. H. Simon, Kazanie biblijne, dz. cyt., s. 75-77.

7 Świata nie należy ukazywać w homilii wyłącznie w opozycji do Boga, ale jako Jego dzieło. Świat ma swoją teologiczną godność. Bóg tak umiłował świat, że Syna swego Jednorodzonego dał $(\mathrm{J} 3,16)$, aby doprowadził On świat do zjednoczenia z Bogiem. Por. A. Lewek, Wspótczesna odnowa kaznodziejstwa, z. 2, Warszawa 1980, s. 167-169.

8 NOWMR - Kongregacja Kultu Bożego i Dyscypliny Sakramentów, Nowe Ogólne Wprowadzenie do Mszału Rzymskiego, 2002; IO - Święta Kongregacja Obrzędów, Instrukcja o należytym wykonywaniu Konstytucji o świętej liturgii „Inter oecumenici”, 1964; LI - Święta Kongregacja Kultu Bożego, Trzecia instrukcja o należytym wykonaniu Konstytucji o świętej liturgii „Liturgicae instaurationes", 1970.

9 H. Simon, Przepowiadanie biblijne, w: Biblia w nauczaniu chrześcijańskim, red. J. Kudasiewicz, Lublin 1991, s. 70-78.

10 Por. J. A. Nalaskowski, Słowo Boże urzeczywistniające Kościót, w: Teologia przepowiadania Słowa Bożego, red. L. Kuc, Warszawa 1971, s. 145.

11 Por. J. Twardy, Aktualizacja słowa Bożego..., dz. cyt., s. 154.

12 Por. Z. Grzegorski, Wprowadzenie do teorii przekazu, w: Praktyka przepowiadania Słowa Bożego, t. 2, red. L. Kuc, Warszawa 1973, s. 130. 
analogicznym do egzegezy biblijnej. Chodzi o rozpoznanie przesłania i działania Bożego w życiu ludu gromadzącego się podczas liturgii i w społeczeństwie, w którym on żyje, o rozeznawanie i interpretowanie znaków, w których ujawnia się inspiracja i działanie Ducha Świętego. Jest to wręcz nakaz ewangeliczny (por. Mk 16, 3), o czym przypomniał papież Jan XXIII ${ }^{13}$. Konstytucja duszpasterska o Kościele w świecie współczesnym Gaudium et spes stwierdza: „Kościół zawsze ma obowiązek badać znaki czasów i wyjaśniać je w świetle Ewangelii, tak aby mógł w sposób dostosowany do mentalności każdego pokolenia odpowiadać ludziom na ich odwieczne pytania dotyczące sensu życia obecnego i przyszłego oraz wzajemnego ich stosunku do siebie. Należy zatem poznawać i rozumieć świat, w którym żyjemy, a także jego nieraz dramatyczne oczekiwania, dążenia i właściwości”(GS 4).

\section{Znaki czasów}

Znaki czasów kojarzą się z rzeczywistością religijną i socjologiczną. $\mathrm{W}$ pierwszym znaczeniu chodzi o sens interwencji Boga w pewnych momentach historii wzywających do nawrócenia. W znaczeniu socjologicznym są to symbole historycznego rozwoju, czy zmian społecznych (np. pojawienie się świata pluralistycznego, globalizacja). W tym znaczeniu są „znakami nowego czasu” (np. pierwsza wiadomość wysłana przez Internet w 1972 roku). W literaturze przedmiotu sugeruje się używać tego terminu w liczbie mnogiej jako „znaki czasów” (łac. signum temporis) w sensie znaki historii, dziejów. Nie należy bowiem kojarzyć ich jedynie jako incydentalnych interwencji Boga w pewnym czasie, ale przejaw permanentnego dialogu zbawczego Boga ze swoim ludem w historii $^{14}$. Według Pawła VI wyrażenie to zyskało znaczenie „teologicznej

13 Por. Jan XXII, Konstytucja apostolska „Humanae salutis”, https://opoka.org.pl/ biblioteka/W/WP/jan_xxiii/konstytucje/humanae_salutis_25121961.html (06.10.2018).

14 Por. A. Kasprzak, Recepcja teologii „znaków czasów” o. Marie-Dominique’a Chenu na Soborze Watykańskim II, w: Recepcja i wyzwania Soboru Watykańskiego II, red. M. Jagielski, Zielona Góra 2018, s. 79-81. 
interpretacji współczesnej historii" ${ }^{15}$. Konstytucja o Kościele w świecie współczesnym podaje iż Lud Boży „stara się w wydarzeniach, potrzebach i pragnieniach, w których uczestniczy z resztą ludzi naszej doby, rozpoznać, jakie w nich mieszczą się prawdziwe znaki obecności lub zamysłów Bożych" (GS 11). W stwierdzeniu tym zauważalna jest teologia dominikanina Marie-Dominique’a Chenu, która traktuje znaki czasów jako fenomeny wyrażające potrzeby i oczekiwania aktualnego pokolenia na Boga, który przyszedł. Tworzą one aktualną sposobność do przyjęcia Ewangelii ${ }^{16}$. Są specyficzną mową świata do Kościoła i swoistym głosem Bożym do Kościoła wypowiadanym przez świat ${ }^{17}$. Nie są bezpośrednim słowem Bożym, ale śladem działania Bożego. Tworzą się na skutek działania Ducha Świętego w sercach ludzi dobrej woli, którzy poruszeni łaską tworzą zjawiska społeczne. Znaki te określane są jako „zasoby otwarcia na łaskę”, „miejsca oczekiwania” Boga na współpracę z człowiekiem w tworzeniu historii ${ }^{18}$, czy „znamienne zjawiska kultury współczesnej”, w których ukryte jest ,jakieś pokrewieństwo Ewangelii ze zbawczą i eschatologiczną rzeczywistością", będące w planach Opatrzności wskazówką i wezwaniem dla Kościoła. Są to wydarzenia historyczne związane ze zbawczą inicjatywą Boga - realizującego swe przymierze wobec człowieka - i rozwijającą się w świecie inicjatywą Ducha Świętego. Obejmują potrzeby moralne, społeczne, ekonomiczne, pragnienia i oczekiwania ludzi współczesnych ${ }^{19}$.

Teologia znaków czasów opiera się na Wcieleniu Syna Bożego. Słowo Odwieczne weszło w historię, w dialog z wydarzeniami świata. Kościół zaś - co podkreśla Chenu - jest tego świadkiem, gdyż jest obecnością Chrystusa w świecie na każdym etapie rozwoju historii. Kościół „jest w akcie miejscem teologicznym teraźniejszej prawdy Ewangelii;

15 Por. Paweł VI, Przemówienie na audiencji generalnej (16.04.1969), https://opoka.org.pl/ biblioteka/W/WP/pawel_vi/audiencje/ag_16041969.html (06.10.2018).

16 Por. A. Kasprzak, Recepcja teologii „znaków czasów”..., dz. cyt., s. 91.

17 Por. A. Lewek, Wspótczesna odnowa kaznodziejstwa, z. 2, Warszawa 1980, s. 171; por. Z. Grzegorski, Wprowadzenie do teorii przekazu, s. 122.

18 Por. S. T. Zarzycki, Znaki czasu, w: Leksykon duchowości katolickiej, red. M. Chmielewski, Lublin-Kraków 2002, s. 962.

19 Por. A. L. Szafrański, Kairologia. Zarys nauki o Kościele w świecie współczesnym, Lublin 1990, s. 109-111. 
jest w akcie dzisiaj, jako świadek ekonomii zbawienia w historii. Czas dostarcza mu znaków obecnego oczekiwania przybyłego Mesjasza, znaków zgodności pomiędzy Ewangelią a nadzieją ludzi"”o. Kościół, głosząc słowo Boże ludziom żyjącym we współczesnym świecie, może powtarzać za Chrystusem „dziś spełniły się słowa Pisma”. Kościół jest zainteresowany światem, jeśli nawet świat nie jest zainteresowany Kościołem. Wynika to z bezinteresownej miłości Chrystusa, w której uczestniczy jako Jego Oblubienica. W tym duchu należy interpretować zachętę papieża Jana XXIII do tzw. aggiornamento, czyli uwspółcześnienia Kościoła do warunków życia współczesnych ludzi poprzez inkulturację i akomodację, także w posłudze słowa. Papież Franciszek zauważa, że „w wierze podoba nam się, żeby mówiono do nas w kluczu «kultury ojczystej 'macierzyńskiej'» w kluczu ojczystego - «macierzyńskiego» dialektu (por. 2 Mch 7, 21. 27), i wtedy serce przygotowuje się, by słuchać lepiej" (EG 139).

Znaki czasów mogą występować jako wydarzenia, zjawiska lub procesy społeczne (lokalne lub globalne). Wydarzenia mogą inicjować zjawiska i procesy albo być ich akcydentalnym wyrazem. Homilia skierowana jest do konkretnego zgromadzenia liturgicznego, więc trzeba najpierw wziąć pod uwagę wydarzenia dotyczące zgromadzonej wspólnoty, a następnie dokonać ich diagnozy w kontekście zjawisk i procesów obejmujących społeczeństwo, w którym żyją wierni. Odwrotne postępowanie może prowadzić do pochopnej i błędnej interpretacji życia słuchaczy, a co za tym idzie do mówienia o tym, co ich nie dotyczy, choć nie wykluczone, że może mieć na nich wpływ w niedalekiej nawet przyszłości, na skutek np. globalizacji, czy komunikacji masowej. Homilista musi stwierdzić: czy ma do czynienia z pewną tendencją we wspólnocie, czy z jednostkowym incydentem, przewidując roztropnie ewentualne skutki wydarzeń, zjawisk i zachowań, żeby prowadzić wspólnotę we właściwym kierunku. Ewangelia dzieje się w Ludzie Bożym, który jest wspólnotą dynamiczną i nie może on być potraktowany jak muzeum, czy skansen sentymentów

20 Por. M. D. Chenu, Les signes des temps, „Nouvelle Revue Théologique” (1965) nr 1508, s. 36, cyt. za A. Kasprzak, Recepcja teologii „znaków czasów”..., dz. cyt., s. 85. 
religijnych, a zgromadzenie liturgiczne - jak grupa rekonstrukcyjna obrzędów sakralnych ${ }^{21}$.

W tym miejscu warto zwrócić uwagę na kulturę szeroko rozumianą, zarówno sztukę, jak i kulturę ludową. Jest ona niejako twarzą ludu, na której widać co on przeżył i doświadcza. Zdaniem Franciszka: „pojęcie kultury jest cennym narzędziem do zrozumienia różnych form życia chrześcijańskiego, występujących w Ludzie Bożym. Chodzi o styl życia określonej społeczności, o szczególny sposób relacji, jakie jego członkowie utrzymują ze sobą, z innymi stworzeniami oraz z Bogiem. [...] Człowiek jest zawsze usytuowany kulturowo: «natura i kultura łączą się ze sobą jak najściślej». Łaska zakłada kulturę, a Boży dar wciela się w kulturę tego, który go przyjmuje” (EG 115). Według papieża „przepowiadanie chrześcijańskie znajduje w sercu kultury ludu źródło wody żywej, zarówno żeby wiedzieć, co należy mówić, jak i znaleźć właściwy sposób, by to powiedzieć" (EG 139). Kultura danego ludu przeniknięta Ewangelią staje się kulturą Ludu Bożego, ponieważ „gdy jakaś wspólnota przyjmuje orędzie zbawienia, Duch Święty zapładnia jej kulturę przemieniającą mocą Ewangelii. [...] Przez inkulturację Kościół «wprowadza narody z ich kulturami do swej własnej wspólnoty» [...] przyswajając sobie wartości różnych kultur" (EG 116) 22 .

Fenomen kultury poddany został naukowym analizom w środowisku Katolickiego Uniwersytetu Lubelskiego (Karol Wojtyła, Mieczysław A. Krąpiec, Czesław S. Bartnik). W świetle dokonanych analiz kultura

${ }^{21}$ Zgromadzenie liturgiczne może być zróżnicowane pod względem wieku, płci, wykształcenia, zamożności, statusu społecznego czy nawet rasy. Por. H. Sławiński, Homilia niedzielna. Dokumenty Konferencji Episkopatu Stanów Zjednoczonych, Kraków 2015, s. 96.

Członkowie zgromadzenia liturgicznego podlegają wpływom społeczeństwa, w którym żyją, szczególnie grup społecznych w jakich się wychowują i funkcjonują, np.: rodzina, szkoła, współpracownicy. Por. M. Paciuszkiewicz, Struktury przepowiadania, w: Praktyka przepowiadania Słowa Bożego, t. 2, red. L. Kuc, Warszawa 1973, s. 172-173.

22 Współcześnie w społeczeństwo wielokulturowym musimy niejako na nowo definiować pojęcie kultury. Franciszek wskazuje nam, że „nowe kultury rodzą się nadal na ogromnych obszarach ludzkości, gdzie chrześcijanin nie jest już promotorem lub twórcą sensu, natomiast otrzymuje od nich inne języki, symbole, przesłania i wzorce, ofiarujące nowe orientacje życia, często sprzeczne z Ewangelią Jezusa. Nieznana dotychczas kultura pulsuje i projektowana jest w miastach”. Stanowi to wyzwania, a nawet „uprzywilejowane miejsce dla nowej ewangelizacji (EG 73). 
to „wszelkiego rodzaju wytwory człowieka, jako rezultat jego osobowego działania (świadomego i dobrowolnego)". Jest ona swoistą racjonalizacją (intelektualizacją) natury (przyrody i samego człowieka). Jest „uczłowieczeniem rzeczywistości” czy raczej „personalizacją człowieka i świata”" . Jan Paweł II stwierdził, że kultura jest „właściwym kształtem życia człowieka jako takiego", ,właściwym sposobem istnienia i bytowania człowieka" "24. Jest „tym, przez co człowiek, jako człowiek, staje się bardziej człowiekiem" ${ }^{25}$.W kontekście tak pojętej kultury można rozeznawać i interpretować znaki czasów, rozróżniając za Janem Pawłem II cywilizację życia i śmierci, ludzką i zdehumanizowaną, inspirowaną przez Ducha Świętego, działającego nawet w ukryciu ludzkich serc niewierzących i tę sprzeciwiającą się Jemu.

\section{Proces rozeznawania i interpretacji znaków czasów}

Rozeznawanie i interpretowanie znaków czasów jest procesem złożonym. Inicjatywy człowieka w świecie są bowiem ambiwalentne i należy odróżnić inicjatywy wyłącznie ludzkie od Bożych - o czym sygnalizował francuski teolog Poul Valadier ${ }^{26}$. Karl Rahner wskazywał na niebezpieczeństwo pomieszania kwestii łaski wynikającej z porządku naturalnego i nadprzyrodzonego ${ }^{27}$. Francuski teolog Claude Geffré, w roku 1982, przestrzegał przed popadnięciem $\mathrm{w}$, całkowicie antropomorficzną wizję działania Boga w historii, tak jakby Bóg miał być bardziej zaangażowany w pewnych

23 Badania prowadzone nad tym zagadnieniem korelowały $\mathrm{z}$ fenomenologią i metafizyką. Por. J. Szymik, Teologia rozmowa o Bogu i człowieku, Lublin 2008, s. 29-30.

24 Człowiek bytuje zawsze na sposób jakiejś kultury sobie właściwej, która z kolei stwarza pomiędzy ludźmi właściwą dla nich więź, stanowiąc o międzyludzkim i społecznym charakterze ludzkiego bytowania. Jan Paweł II, Przyszłość człowieka zależy od kultury. Przemówienie wygłoszone 2 czerwca 1980 roku w UNESCO, p. 6, http://wiez.pl/laboratorium/teksty. php?przyszlosc_czlowieka_zalezy_od_kultury_przemowieni\&p=3 (06.10.2018).

25 Jan Paweł II, Przyszłość człowieka zależy od kultury. Przemówienie wygłoszone 2 czerwca 1980 roku w UNESCO, p. 7, http://wiez.pl/laboratorium/teksty.php?przyszlosc_czlowieka_ zalezy_od_kultury_przemowieni\&p=3 (06.10.2018).

26 Por. A. Kasprzak, Recepcja teologii „znaków czasów”..., dz. cyt., s. 100.

27 Por. A. Kasprzak, Recepcja teologii „znaków czasów”..., dz. cyt., s. 90. 
wydarzeniach”. Stwierdzał, że „ostatecznie wszystko, co się przeżywa w dziedzinie relacji ludzkich, ekonomicznych, politycznych, nauki i kultury znajduje swój ostateczny sens jedynie w zależności od relacji zasadniczej pomiędzy człowiekiem a Bogiem"28. Dlatego potrzeba właściwej hermeneutyki rozeznawania, aby nie doprowadzić do uproszczonej czy błędnej interpretacji, która raczej mnoży zamiast rozwiązywać problemy.

Zdaniem Chenu znaki czasów, jako wydarzenia ludzkie trzeba „rozpoznawać według ich własnych praw, bez przedwczesnego określania ich jako nadprzyrodzone”29. Według niego chodzi o „szukanie znaków wcielenia Słowa w człowieku”, który jest ,podmiotem łaski, capax Dei”30. Interpretując znaki czasów trzeba wystrzegać się, jak zaznaczył papież Paweł VI, z jednej strony charyzmatycznego profetyzmu, a z drugiej opisu objawowego czy arbitralnego i subiektywnego interpretowania. Pierwszy przechodzi w bigoteryjną fantazję, kiedy ktoś zapomina o złożoności życia ludzkiego i przypisuje cudowny charakter przypadkowym zbiegom okoliczności bądź rzeczom nieistotnym. Natomiast błąd objawowego opisu polega na tym, że wydarzenia i procesy społeczne opisuje się wyłącznie przy pomocy schematów technicznych i socjologicznych, pomijając ich odniesienie do objawienia Bożego. Papież Franciszek przestrzega przed przesadną diagnostyką i spojrzeniem czysto socjologicznym, bo ono „swą metodologią chce ogarnąć całą rzeczywistość w sposób tylko hipotetycznie neutralny i aseptyczny”. Postuluje raczej „spojrzenie misyjnego ucznia, «ożywiane światłem i mocą Ducha Świętego»" i „ewangeliczne rozeznanie” (EG 50), w którym człowiek przy pomocy Ducha Świętego stara się rozpoznać „Boże wezwanie, rozbrzmiewające w określonej sytuacji historycznej” (EG 154). Duch Święty pobudza zmysł wiary, który - jak zaznaczył papież Pawła VI - udziela „daru świadomego jasnowidzenia”.Jednakże zawsze decydująca będzie przy tym pomoc magisterium hierarchicznego ${ }^{31}$.

28 Cl. Geffré, Éclatement de l'histoire et Seigneurie du Christ, „Transversalités” $1982 \mathrm{nr} 3$, s. 11, cyt. za. A. Kasprzak, Recepcja teologii „znaków czasów”..., dz. cyt., s. 101.

${ }_{29}$ M. D. Chenu, Les signes des temps, dz. cyt., s. 34, cyt. za A. Kasprzak, Recepcja teologii „znaków czasów”..., dz. cyt., s. 94.

30 A. Kasprzak, Recepcja teologii „znaków czasów”..., dz. cyt., s. 97.

31 Por. Paweł VI, Przemówienie na audiencji generalnej (16.04.1969), https://opoka.org.pl/ biblioteka/W/WP/pawel_vi/audiencje/ag_16041969.html (06.10.2018). 
W procesie rozeznawania i interpretowania znaków czasów należy przejść od znaku do rzeczywistości, którą on wyraża. Dodać trzeba, że treść znaków czasów nie jest przedmiotem przepowiadania homilijnego, ale przedmiotem dialogu zbawczego realizowanego w homilii. Znaki czasów nie są równe słowu Bożemu i Tradycji. Wskazane jest też, aby homilista interpretował sprawy doczesne w perspektywie celów ostatecznych człowieka, materialne - w kontekście duchowych, a rzeczowe i społeczne - w perspektywie osobowej. Głoszący słowo Boże musi uważać, aby nie zdeformować wiary słuchaczy i nie sprowadzić jej do zabobonu. Luis Maldonado wskazuje, że homilia musi być lekturą aktualnych znaków w odniesieniu do wyjaśnianego tekstu, aby pokazać, jak ono się spełnia. Wymienia przy tym trzy rodzaje znaków. Pierwszy - to życie Kościoła jako całej społeczności i poszczególnych wiernych. Drugi wiąże się z celebracją sakramentalną, zwłaszcza Eucharystią, w której Kościół uobecnia się jako wspólnota liturgiczna. Trzeci to życie pojedynczych ludzi lub grup w społeczeństwie, w których przez obecność wartości ewangelicznych wyraża się Duch Święty ${ }^{32}$. Papież Franciszek w adhortacji apostolskiej Evangelii gaudium postuluje taką wrażliwość duchową homilistów, która pozwala „w wydarzeniach odczytywać przesłanie Boże”, czyli to „co Pan pragnie powiedzieć w określonych okolicznościach”. Zakłada przy tym poszukiwanie Boga w perspektywie konkretnych przejawów życia wspólnoty. Zdaniem papieża homilista powinien poznawać daną społeczność ludzką, „zwracając uwagę «na konkretny lud z jego znakami i symbolami, i odpowiadając na pytania, jakie stawia»" (EG 154).

Egzegeza homilijna działania Ducha Świętego w życiu Ludu Bożego jest procesem bardzo subtelnym, a proces rozeznawania i interpretowania znaków czasów łatwo może przerodzić się w projekcję nastawienia i odczuć homilisty wobec słuchaczy homilii. Dlatego należy przyjąć pewne paradygmaty (modele rozumowania i interpretowania rzeczywistości), stosować określoną metodę i przestrzegać konkretnych wskazań.

32 Por. L. Maldonado, L’omelia. Predicazione, liturgia, comunitá, tłum. V. Schiavone, Madryt 1992, s. 12-13. 


\section{Paradygmaty procesu rozeznawania}

W rozeznawaniu i interpretacji kultury, a przez nią rzeczywistości, w której pojawiają się interesujące nas znaki czasów proponuję przyjać paradygmat personalistyczno-chrystocentryczny, jako podstawowe kryterium rozeznania, ponieważ Chrystus jest „Pierworodnym wobec każdego stworzenia" (Kol 1, 15). Jest więc paradygmatem osobowego istnienia człowieka.

Pierwszy element paradygmatu wiąże się z normą personalistyczną. Antropologia rozróżnia akt człowieka i akt ludzki. Ten pierwszy dokonuje pojedyncza osoba naznaczona osobistymi cechami, bez dostatecznej refleksji, a nawet w afekcie. Akt ludzki to taki, w którym człowiek jako osoba działa świadomie, w sposób wolny i w relacji osobowej wobec innych ludzi ${ }^{33}$. Według Karola Wojtyły akt ludzki jest aktem osoby (łac. actus personae $)^{34}$. Wyzwala on naturę osoby ludzkiej. Zachodzi w nim autorealizacja i personalizacja człowieka, który przez taki czyn staje się osobą „bardziej” i „prawdziwiej” 35 . Akt ludzki posiada więc wartością personalistyczną. W związku z tym Wojtyła wskazał tzw. normę personalistyczną. Nakazuje ona człowiekowi odnosić się do drugiego człowieka jako drugiej osoby $^{36}$.

Aspekt personalistyczny pozwala badać przejawy kultury (materialne i duchowe), by stwierdzać wstępnie, czy jest to kultura ludzka, czy mamy do czynienia z przejawami działania człowieka, który nie tyle realizuje siebie jako osobę, ale wyraża w sposób bardzo hermetyczny swoje wewnętrzne stany i prywatne nastawienie do świata. Współczesną kulturę i sztukę trudno obiektywnie interpretować, bo nierzadko jej twórcy odchodzą od znanych kodów kulturowych i odcinają się od relacji osobowej z Bogiem czy ludźmi. Stąd hermeneutyka interpretacji różnych dzieł oscyluje wokół ich „ego”, ich stanów emocjonalnych, przeżyć

33 Por. K. Wojtyła, Osoba i czyn oraz inne studia antropologiczne, red. T. Styczeń, wyd. 3, Lublin 2000, s. 79 (Człowiek i Moralność, 4).

34 Por. K. Wojtyła, Osoba i czyn..., dz. cyt., s. 73-75.

35 Por. A. Wójtowicz, Osoba i transcendencja. Karola Wojtyły antropologia wiary i Kościoła, Wrocław 1993, s. 201.

36 Por. J. Galarowicz, Etyka, Kraków 1992, s. 518. 
wewnętrznych i tylko autor dzieła potrafi wyjaśnić, co miał na myśli. Tymczasem kultura prawdziwie ludzka jest personalna i personalizująca i jako taka może wyrażać w tym, co ludzkie Boże natchnienie i kierować człowieka ku drugiemu człowiekowi i Bogu.

Drugi element paradygmatu zakłada chrystocentryzm inkarnacyjny. Ksiądz Jerzy Szymik zauważył, że we współczesnych przekształceniach cywilizacyjno-kulturowych poszukuje się nowego paradygmatu charakteryzującego się „inkarnacyjnością”, która oznacza tu wcielenie idei, przyobleczenie ducha szlachetnej abstrakcji w konkret ciała, życia. Za Karlem Rahnerem stwierdza, że owo pragnienie nowego paradygmatu to ruch chrystologiczny. Konstatuje przy tym, że żyjemy w „czasach, w których paradygmat inkarnacji ma swój niepowtarzalny kairos”. Dostrzega z przenikliwą sobie intuicją teologiczną, że „Wydarzenie Chrystusa” jest paradygmatem sensu świata, a Wcielenie to „absolutny i uniwersalny model kultury". Celem zaś kultury osadzonej na paradygmacie inkarnacji jest przybrać kształt-postawę Chrystusa, to znaczy jednocześnie zgodzić się na uczestnictwo w losie Jezusa. Zdaniem Szymika „kultura przybierająca kształt tej zgody” jest chrystokształtna ${ }^{37}$. Aspekt chrystocentrycznej inkarnacyjności paradygmatu pozwala w rozeznawaniu i interpretowaniu kultury, odróżnić co w niej jest chrystokształtne (od Chrystusa wywiedzione i do Niego prowadzące), przez co człowiek może wyrażać wiarę w Jezusa Chrystusa i przyjmować Jego postawę wobec Boga Ojca, ludzi i świata, a co jest zgoła obce i przeciwne Chrystusowi (także antychrześcijańskie).

37 Por. J. Szymik, Teologia rozmowa o Bogu i człowieku, dz. cyt., s. 33-35. Autor zauważa współcześnie zastępowanie powyższego paradygmatu paradygmatem Nirwany. Wyrazem tego, zdaniem teologa, jest „programowa rozpacz, spychanie sztuki w «zaułek ciemności» histeryczne reakcje wpływowej publicystyki na takie pojęcia, jak «styl wysoki», «wartości», «żarliwość», «nadzieja». Oddanie rządu dusz w ręce "generacji nic»; ironia jako podstawowy wyznacznik inteligencji, ironia i sarkazm jako klucz hermeneutyczny do obwieszczania kolejnych śmierci (Boga, historii, człowieka). Buddyzm - w różnych wersjach: od głębokich po tanie, ściągnięte z półek supermarketu - jako postchrześcijański sposób na kłopoty ze współczesnością" (por. J. Szymik, Teologia rozmowa o Bogu i człowieku, dz. cyt., s. 37-38). 


\section{Metoda rozeznawania}

Metodę rozeznawania znaków czasu określa trójmian czynności: widzieć - oceniać - działać. Punktem wyjścia jest poznanie i opis rzeczywistości, np. zjawisk społecznych, potrzeb egzystencjalnych ludzi, tendencji społecznych o niepodważalnej wartości, takich jak poczucie braterstwa i solidarność międzyludzka. Na tym etapie można prowadzić zwyczajną obserwację życia lub badania socjologiczne. Następnie, w drugim etapie, ich wyniki należy poddać interpretacji i ocenie teologicznej ${ }^{38}$, aby przejść od znaku (łac. significans) do rzeczywistości, którą on oznacza (łac. significatum). Należy więc postrzegać znaki czasów przez pryzmat wiary, która „ujawnia Boży zamysł” (GS 11), aby odróżnić działanie Boże od działania jedynie człowieka ${ }^{39}$. Homilista powinien przy tym wystrzegać się przesadnej introspekcji czy autorefleksji, aby nie interpretować pewnych zjawisk wyłącznie ze swojego punktu widzenia. W niektórych przypadkach pomocne i konieczne będzie odwołanie się do orzeczeń Urzędu Nauczycielskiego Kościoła, dokumentów papieskich, zwłaszcza tych, które podejmują aktualne problemy współczesnego człowieka. Etap trzeci zachodzi na płaszczyźnie interpersonalnej relacji człowieka wierzącego z Bogiem i polega na ustosunkowaniu się do działania Boga i współdziałanie z Nim. Chodzi o swoiste nawrócenie pastoralne ${ }^{40}$.

W prezentowanej metodzie najpierw trzeba dostarczyć materiału do analizy. Dlatego szerzej zostaną omówione czynności służące poznaniu sytuacji egzystencjalnej potencjalnych słuchaczy homilii. Homilista zdobywa wiedzę o ich życiu przez własne doświadczenie życiowe, obserwację codziennego życia, spotkania z ludźmi, nauki humanistyczne, literaturę i środki społecznego komunikowania. Szczególnie ważne są spotkania i rozmowy z indywidualnymi osobami lub grupami ludzi,

38 Por. J. Szymik, Teologia rozmowa o Bogu i człowieku, dz. cyt., s. 129. Pożytecznym narzędziem w interpretacji życia słuchaczy homilii są psalmy, które wyrażają uczucia i postawy ludzkie w kontekście misterium Chrystusa. Chrystologiczna egzegeza psalmów rzuca światło na doświadczenia człowieka. Por. S. Dyk, Homilia. Droga do żywego poznania Misterium Chrystusa, Kielce 2016, s. 150.

39 Por. S. T. Zarzycki, Znaki czasu, dz. cyt., s. 960-961.

40 Por. S. Bielecki, Teologia znaków czasu, dz. cyt., s. 189-193. 
np. podczas odwiedzin duszpasterskich, zwłaszcza w sytuacjach granicznych takich, jak choroba czy śmierć kogoś bliskiego, ponieważ wtedy ludzie chętniej się otwierają ${ }^{41}$. Homilista przez obserwację czy rozmowy z ludźmi może uświadomić sobie nie tylko o czym mówią, ale również co przemilczają, a co może być dla nich trudne ${ }^{42}$.

Poznaniu sytuacji egzystencjalnej słuchaczy homilii pomagają również nauki humanistyczne i różne analizy: antropologiczne, socjologiczne, psychologiczne, filozoficzne, demograficzne, etnograficzne, kulturowe i historyczne, a nawet ekonomiczne ${ }^{43}$. Do korzystania z nich zachęca Sobór Watykański II (GS 62). Pod uwagę można wziąć też kościelne statystyki aktywności religijnej wiernych (dominicantes i communicantes). Warto również posłużyć się niektórymi metodami jakościowymi badań socjologicznych, np.: obserwacją, wywiadem jakościowym i zogniskowanym wywiadem grupowym.

Podczas obserwacji homilista może być anonimowy, aby lepiej uchwycić zwykłe zachowania ludzi. Może również być obserwatorem jako znany uczestnik społeczności, zwłaszcza wspólnoty parafialnej. Może też przyjąć rolę obserwatora, uczestnicząc w spotkaniach grupy badanych osób, np. grup pastoralnych bądź grup nieformalnych. Wreszcie może wystąpić jako „całkowity obserwator” w miejscach publicznych ${ }^{44}$.

Wywiad jakościowy przypomina codzienną rozmowę, ale jest metodycznie ukierunkowany. Przepowiadający bardziej słucha niż mówi, aby dotrzeć do „świata przeżyć, sensów, interpretacji osoby udzielającej wywiadu”. Może on nakłaniać rozmówcę do prostego wyjaśniania potrzeb życiowych, stawiając pytania kierujące, np.: „Jak to jest?”, „W jaki

${ }^{41}$ Również posługa w sakramencie pokuty i pojednania sprzyja poznaniu ludzkich potrzeb. Żeby jednak nie wyjawić tajemnic spowiedzi, które obowiązują szafarzy i nie zrazić penitentów, mówiący nie powinien przywoływać konkretnych przykładów, ale tylko powszechne procesy i doświadczenia życiowe. Jan Twardy uważa, że nigdy nie należy powoływać się na spowiedź, choćby w sposób ogólny, czy też na fakty z nią związane. Wszakże sytuacje z życia penitentów mogą być powszechne, a wiedza o nich pochodzić z innych źródeł niż spowiedź. Por. J. Twardy, Aktualizacja słowa Bożego..., dz. cyt., s. 249-251.

42 Por. A. Schwarz, Jak pracować nad kazaniem, Warszawa 1993, s. 59.

43 Por. H. Sławiński, Homilia niedzielna, dz. cyt., s. 17.

44 S. Grotowska, Metody jakościowe w socjologii, w: Socjologia życia religijnego w Polsce, red. S. H. Zaręba, Warszawa 2009, s. 182-191. 
sposób?”, „Co ma Pan/Pani na myśli?”, „Czy mógłby Pan/Pani podać przykład?”, „Dlaczego Pan/Pani tak sądzi?”, „Czy mógłby Pan/mogłaby Pani powiedzieć o tym coś więcej?”. Na początku może stawiać pytania natury ogólnej, aby ośmielić rozmówcę, a potem konkretne pytania o motywy działania, aż po pytania egzystencjalne i metafizyczne o sens życia człowieka ${ }^{45}$. Podobną rolę pełnią tzw. „kręgi przygotowawcze” oraz „kręgi dyskusyjne”"46, skupiające homilistów i świeckich, np. członków grup pastoralnych. Podczas nich można zachęcać wiernych do stawiania pytań na temat poprzedniej homilii, ewangelii z poprzedniej lub następnej celebracji liturgicznej czy codziennych spraw. Metodą analizy potrzeb wiernych może być też ankieta homiletyczna. Stawiane w niej pytania powinny być otwarte i nie mogą sugerować z góry przyjętej interpretacji życia ${ }^{47}$.

Zogniskowany wywiad grupowy to dyskusja prowadzona przez moderatora w grupie ok. 9 osób. Metoda ta może pokryć się z przygotowaniem homilii w grupie. Zakłada nawet kilka wywiadów z grupami zróżnicowanymi pod względem cech takich, jak np. wiek, płeć, sytuacja zawodowa czy rodzinna. W takim wywiadzie zachodzą prawa dynamiki grupowej; wypowiedzi jednych osób pobudzają innych uczestników do zajęcia stanowiska. Przypomina to interakcje społeczne. Moderatorem panelu dyskusyjnego może być homilista lub osoba wyznaczona przez niego, np. posiadająca odpowiednie do tego kompetencje $e^{48}$.

Do ważnych źródeł poznania ludzkiej egzystencji, w tym ludzkich obaw, dążeń, pragnień, oczekiwań i pytań o sens i przeznaczenie człowieka należą: współczesna literatura, poezja i szeroko pojęta sztuka. Są one wyrazem doświadczeń ludzi (GS 62). Opisują „fenomenem ludzkiego życia”. W literaturze zawarte jest „misterium egzystencji” człowieka, które ma wiele elementów wspólnych z Bibliąa9 .

45 S. Grotowska, Metody jakościowe w socjologii..., dz. cyt., s. 182-191.

46 H. Simon, Kazanie biblijne, dz. cyt., s. 81-86.

47 Por. J. Twardy, Aktualizacja słowa Bożego..., dz. cyt., s. 251-254.

48 S. Grotowska, Metody jakościowe w socjologii..., dz. cyt., s. 182-191.

49 Por. H. Simon, Przepowiadanie biblijne, dz. cyt., s. 70-78; por. J. Twardy, Aktualizacja słowa Bożego..., dz. cyt., s. 274-286. 
Homilista może czerpać wiedzę o współczesnym człowieku również przez środki masowego komunikowania: Internet, prasę, radio, telewizję czy inne. Wskazują one, jak ludzie odnoszą się do Boga i innych ludzi, jakie uznają wartości czy też jak interpretują pewne zjawiska ${ }^{50}$. Pozwalają zauważyć pewne tendencje i procesy społeczne. Trzeba jednak zauważyć, że mass media kreują rzeczywistość wirtualną, angażując w nią emocjonalnie ludzi; generują problemy wirtualne, które są jednak faktycznie przeżywane przez odbiorców. Homilista musi je odróżniać i kierować także uwagę słuchaczy na realne potrzeby egzystencjalne, wskazując Bożą odpowiedź na nie ${ }^{51}$.

\section{Wyznaczniki rozeznawania}

Na podstawie powyższych rozważań konieczne wydaje się podanie pewnych wskazań co do homilijnego procesu rozeznawania i interpretowani znaków czasów. Po pierwsze niezbędne jest zwrócenie się w modlitwie do Ducha Świętego, pamiętając o sprawach Ludu Bożego, aby z Nim je skonsultować i rozeznać w nich Jego działanie (por. EG 14). On jest Pierwszym Egzegetą Słowa Bożego i życia Ludu Bożego. Jest duszą Kościoła i jego Żywą Pamięcią. Duch Święty inkarnuje to, co Boże w to, co ludzkie, a jednocześnie wprowadza człowieka w życie Boże. Jest animatorem kultury prawdziwie ludzkiej działającym w sumieniach ludzi. Dlatego tylko z Nim można kontemplować lud, Mistyczne Ciało Jezusa - Kościół. Z Nim należy więc dokonywać swoistego lectio divina nie tylko tekstu biblijnego, czy tekstu liturgii, ale również życia Ludu Bożego. On jest autorem homilii jako wydarzenia zbawczego, jako aktu zbawczego dialogu Pana ze swoim Ludem.

Po drugie, znaki czasów należy rozeznawać i interpretować w konfrontacji z Ewangelią. Dyrektorium homiletyczne, chociaż nie wspomina wprost o znakach czasów, poleca jednak lectio divina, a w niej kontemplację Słowa Bożego „podczas której przyjmujemy - jako dar Boga - Jego

50 H. Simon, Kazanie biblijne, dz. cyt., s. 81-86.

51 Por. R. Hajduk, Posłani głosić dobrą nowinę, Kraków 2007, s. 235-249. 
spojrzenie przy ocenie rzeczywistości”. Dalej stwierdza, że Słowo Boże „jawi się tutaj jako kryterium rozeznania” jako zdolne osadzić pragnienia i myśli serca (DH 27) ${ }^{52}$. W pierwszej kolejności chodzi o spojrzenie homilisty w głąb siebie, aby mógł podzielać Boże spojrzenie na życie ludzi, do których będzie głosił Ewangelię. Aktualną rzeczywistość życia Ludu Bożego trzeba konfrontować z tekstam Pisma Świętego, a także z Tradycją Kościoła. Wtedy dopiero można właściwie zinterpretować mowę Boga w znakach czasu i odpowiedź ludu, biorąc pod uwagę hermeneutykę ciągłości objawienia i rozwoju życia Kościoła, w tym także hermeneutykę rozwoju doktryny i liturgii.

Trzeci wyznacznik odczytywania znaków czasów stanowi kolegialność, rozumiana jak proces wspólnotowego rozeznawania homilisty, hierarchii i wiernych świeckich. Rozeznawanie znaków czasu jest zaleceniem soborowym jako sprawa całego Ludu Bożego. Konstytucja duszpasterska o Kościele w świecie współczesnym podaje wyraźnie, że to Kościół, a nie pojedynczy wierny „ma obowiązek badać znaki czasów i wyjaśniać je w świetle Ewangelii”, aby „Prawda objawiona mogła być ciągle coraz głębiej odczuwana, lepiej rozumiana i stosowniej przedstawiana" (GS 4. 44). Dekret o posłudze i życiu prezbiterów „Presbyterorum ordinis”, wskazuje, że prezbiterzy winni razem ze świeckimi rozpoznawać znaki czasów „uznając ich doświadczenia i kompetencję w różnych dziedzinach ludzkiego działania" (DK 9). O rozpoznawaniu wspólnotowym znaków czasów wspomniał papież Franciszek w adhortacji Evangelii gaudium w kontekście nowej ewangelizacji dla przekazu wiary (EG 14). Zauważył wręcz „potrzebę przyjęcia zbawiennej «decentralizacji»”, aby nie zastępować „lokalne Episkopaty w rozeznaniu wszystkich problemów wyłaniających się na ich terytoriach” (EG 6). Franciszek przypomina, że „Bóg obdarza całość wiernych instynktem wiary - sensus fidei - pomagającym im w rozeznawaniu, co rzeczywiście pochodzi od Boga. Obecność Ducha zapewnia chrześcijanom pewną tożsamość z rzeczywistością Bożą oraz mądrością pozwalającą im pojmować tę rzeczywistość intuicyjnie, chociaż

52 Kongregacja do spraw Kultu Bożego i Dyscypliny Sakramentów, Dyrektorium homiletyczne, tłum. P. Borkowski, Poznań 2015. 
nie dysponują odpowiednimi narzędziami, by ją wyrazić precyzyjnie" (EG 119). Jest to natomiast zadaniem duszpasterzy i teologów.

\section{Zakończenie}

W niniejszym artykule przedstawiona została teologia „znaków czasów" i ich znaczenie w praktyce przepowiadania homilijnego. Wskazano związek między nimi i kulturą ludzką. Respektując naturę własną „znaków czasów”, zaprezentowano paradygmat, metodę i wyznaczniki $\mathrm{w}$ procesie ich rozeznawania i interpretowania. Przeprowadzone analizy wskazują, że trzeba wziąć pod większą uwagę następujące obszary działalności homilistów i homiletów. Po pierwsze uwzględnić bardziej element egzystencjalny w przepowiadaniu i przeprowadzać analizę antropologiczną podczas przygotowania homilii. Po drugie dowartościować kolegialność w rozeznawaniu znaków czasów. Sprzyjać temu moga spotkania kapłańskie, czy spotkania pastoralne grup wiernych świeckich podejmujące refleksję nad aktualnymi wydarzeniami lub zjawiskami społecznymi. Trzeci postulat dotyczy dydaktyki homiletycznej. Kształcąc homilistów i homiletów, należałoby położyć większy akcent na kształtowanie w nich krytycznego, choć nie krytykanckiego, spojrzenia na świat, żeby wyrabiali w sobie przenikliwe spojrzenie z wiarą na społeczeństwo. Czynić to powinno się w duchu słów Pawła Apostoła: „Ducha nie gaście, proroctwa nie lekceważcie! Wszystko badajcie, a co szlachetne - zachowujcie! Unikajcie wszystkiego, co ma choćby pozór zła” (1 Tes 5, 19-22). Ważne przy tym jest utrwalanie właściwej wizji Kościoła, który nie jest twierdzą broniącą się przed tym, co zewnętrzne i zamykającą się w sobie, ale raczej otwartym domem, wspólnotą świadomą swojej istoty i misji we współczesnym świecie. 


\section{Summary}

Rozeznawanie i interpretowanie znaków czasów:

egzegeza homilijna działania Ducha Świętego w życiu Ludu Bożego

Artykuł przedstawia zagadnienie rozeznawania i interpretacji znaków czasów w liturgicznym przepowiadaniu słowa Bożego. Zwraca uwagę, że w przygotowaniu homilii poza egzegezą biblijną i hermeneutyką liturgiczną ważna jest również analiza antropologiczna życia słuchaczy homilii. Jest to swoista egzegeza homilijna działania Ducha Świętego w Ludzie Bożym. W znakach czasów ujawnia się bowiem Jego inspiracja i działanie. Choć nie są one jakościowo równe z Pismem Świętym, są jednak specyficzną mową świata do Kościoła i swoistym głosem Bożym do Kościoła, wypowiadanym przez świat. Wyrażają potrzeby i oczekiwania aktualnego pokolenia wobec Boga. W związku z tym, postulując ewangeliczne rozeznawanie znaków czasów, zaproponowano paradygmat personalistyczno-chrystocentryczny, metodę i konkretne wyznaczniki tego procesu oraz wskazano wnioski wobec praktyki homilijnej i dydaktyki homiletycznej.

Słowa kluczowe: homilia, znaki czasów, kultura, rozeznawanie

Discernment and Interpretation of the Signs of the Times:

Homily Exegesis of the Holy Spirit's Action in the Life of God's People

The article presents the issue of discernment and interpretation of the signs of the times in the liturgical proclamation of the word of God. He points out that in the preparation of the homily, apart from biblical exegesis and liturgical hermeneutics, it is also important to analyze the anthropological life of the homilies' listeners. It is a homily exegesis of the Holy Spirit's action in the People of God. The signs of the times reveal His inspiration and action. Although they are not qualitatively equal to the Scriptures, they are, however, a specific speech of the world to the Church and a specific God's voice to the Church expressed by the world. They express the needs and expectations of the current generation for God. In connection with this, postulating the evangelical discernment of the signs of the times, a personalisticChristocentric paradigm, a method and concrete determinants of this process are proposed, and conclusions for homily practices and homiletic didactics are suggested.

Keywords: homilies, signs of the times, culture, discernment 


\section{Bibliografia}

Pismo Święte Starego i Nowego Testamentu w przekładzie zjęzyków oryginalnych (Biblia Tysiąclecia), wyd. 3 poprawione, red. A. Jankowski, L. Stachowiak, K. Romaniuk, Poznań-Warszawa 1990.

Franciszek, Adhortacja apostolska „Evangelii gaudium” o głoszeniu Ewangelii we wspótczesnym świecie, Kraków 2013.

Jan Paweł II, Przyszłość człowieka zależy od kultury, przemówienie wygłoszone 2 czerwca 1980 roku w UNESCO, http://wiez.pl/laboratorium/teksty.php?przyszlosc_ czlowieka_zalezy_od_kultury_przemowieni\&p=3 (06.10.2018).

JanXXII,Konstytucjaapostolska „Humanaesalutis”, https://opoka.org.pl/biblioteka/W/ WP/jan_xxiii/konstytucje/humanae_salutis_25121961.html (06.10.2018).

Kongregacja Kultu Bożego i Dyscypliny Sakramentów, Nowe ogólne wprowadzenie do Mszału Rzymskiego, Rzym 2002.

Kongregacja do Spraw Kultu Bożego i Dyscypliny Sakramentów, Dyrektorium homiletyczne, Poznań 2015.

Paweł VI, Przemówienie na audiencji generalnej (16.04.1969), https://opoka.org.pl/ biblioteka/W/WP/pawel_vi/audiencje/ag_16041969.html (06.10.2018).

Sobór Watykański II, Dekret o posłudze i życiu prezbiterów „Presbyterorum ordinis”, w: Sobór Watykański II. Konstytucje, dekrety, deklaracje, tekst polski, Poznań 2002, s. 478-508.

Sobór Watykański II, Konstytucja duszpasterska o Kościele w świecie współczesnym „Gaudium et spes”, w: Sobór Watykański II. Konstytucje, dekrety, deklaracje, tekst polski, Poznań 2002, s. 537-620.

Święta Kongregacja Kultu Bożego, „Liturgicae instaurationes”. Trzecia instrukcja o należytym wykonaniu Konstytucji o świętej liturgii, 1970, „Wiadomości Archidiecezjalne Warszawskie" 61 (1971), s. 135-142.

Święta Kongregacja Obrzędów, Instrukcja o należytym wykonywaniu Konstytucji o świętej liturgii „Inter oecumenici”, 1964, http://www.komkultubozego.episkopat. $\mathrm{pl} / \mathrm{id}=89$ (19.08.2019).

Bielecki S., Teologia znaków czasu, Kielce 2006.

Cygański A., Dialogiczny wymiar homilii po Soborze Watykańskim II, Kraków 2018.

Dyk S., Homilia. Droga do żywego poznania Misterium Chrystusa, Kielce 2016.

Galarowicz J., Etyka, Kraków 1992.

Grotowska S., Metody jakościowe w socjologii, w: Socjologia życia religijnego $w$ Polsce, red. S. H. Zaręba, Warszawa 2009.

Grzegorski Z., Wprowadzenie do teorii przekazu, w: Praktyka przepowiadania Słowa Bożego, t. 2, red. L. Kuc, Warszawa 1973, s. 74-90.Hajduk R., Posłani głosić dobra nowinę. Podstawowy kurs homiletyczny, Kraków 2007.

Kasprzak A., Recepcja teologii „znaków czasów” o. Marie-Dominique’a Chenu na Soborze Watykańskim II, w: Recepcja i wyzwania Soboru Watykańskiego II, red. M. Jagielski, Zielona Góra 2018, s. 79-105. 
Lewek A., Wspótczesna odnowa kaznodziejstwa, z. 2, Warszawa 1980.

Maldonado L., L'omelia. Predicazione, liturgia, comunitá, tłum. V. Schiavone, Madryt 1992.

Nalaskowski J. A., Słowo Boże urzeczywistniające Kościót, w: Teologia przepowiadania słowa Bożego, red. L. Kuc, Warszawa 1971, s. 67-148.

Paciuszkiewicz M., Struktury przepowiadania, w: Praktyka przepowiadania Stowa Bożego, t. 2, red. L. Kuc, Warszawa 1973, s. 139-192.

Schwarz A., Jak pracować nad kazaniem, Warszawa 1993.

Simon H., Kazanie biblijne. Teoria przepowiadania Bruno Drehera (1911-1971), Opole 1995.

Simon H., Przepowiadanie biblijne, w: Biblia w nauczaniu chrześcijańskim, red. J. Kudasiewicz, Lublin 1991.

Sławiński H., Homilia niedzielna. Dokumenty Konferencji Episkopatu Stanów Zjednoczonych, Kraków 2015.

Szafrański A. L., Kairologia. Zarys nauki o Kościele w świecie wspótczesnym, Lublin 1990.

Szymik J., Teologia rozmowa o Bogu i człowieku, Lublin 2008.

Twardy J., Aktualizacja słowa Bożego w kaznodziejstwie, Przemyśl 2009.

Wojtyła K., Osoba i czyn oraz inne studia antropologiczne, red. T. Styczeń, wyd. 3, Lublin 2000 (Człowiek i Moralność, 4).

Wójtowicz A., Osoba i transcendencja. Karola Wojtyły antropologia wiary i Kościoła, Wrocław 1993.

Zarzycki S.T., Znaki czasu, w: Leksykon duchowości katolickiej, red. M. Chmielewski, Lublin-Kraków 2002. 